\title{
Interleukin 24 Measurement
}

National Cancer Institute

\section{Source}

National Cancer Institute. Interleukin 24 Measurement. NCI Thesaurus. Code C74821.

The determination of the amount of interleukin 24 present in a sample. 